LOCKHEED MARTINY

ENVIRONMENTAL RESTORATION PROGRAM

\title{
Evaluation of Ground Freezing for Environmental Restoration at Waste Area Grouping 5, Oak Ridge National Laboratory, Oak Ridge, Tennessee
}

\section{MASTER}


This report has been reproduced directly from the best available copy.

Available to DOE and DOE contractors from the Office of Scientific and Technical Information, P.O. Box 62, Oak Ridge, TN 37831; prices available from 615-576-8401 (fax 615-576-2865).

Available to the public from the National Technical Information Service, U.S. Department of Commerce, 5285 Port Royal Rd., Springfield, VA 22161. 
Energy Systems Environmental Restoration Program ORNL Environmental Restoration Program

\section{Evaluation of Ground Freezing for Environmental Restoration at Waste Area Grouping 5, Oak Ridge National Laboratory, Oak Ridge, Tennessee}

D. D. Gates

Date Issued-September 1995

Prepared for

U.S. Department of Energy

Office of Environmental Management under budget and reporting code EW 20

managing the

Environmental Restoration Activities at OAK RIDGE NATIONAL LABORATORY

Oak Ridge, Tennessee 37831 managed by

LOCKHEED MARTIN ENERGY SYSTEMS, INC. for the

U. S. DEPARTMENT OF ENERGY under contract DE-AC05-84OR21400 


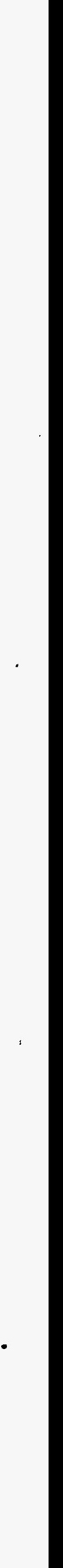




\section{PREFACE}

This report on an Evaluation of Ground Freezing for Environmental Restoration at Waste Area Grouping (WAG) 5 of the Oak Ridge National Laboratory documents remedial action technology development activities performed in accordance with the Record of Agreement, dated June 23, 1994, between the Department of Energy, the Tennessee Department of Environment and Conservation and the Environmental Protection Agency. The Record of Agreement for Oak Ridge National Laboratory WAG 5 recognizes the need to develop or adapt and demonstrate innovative technologies for all phases of site remediation. This work was performed under Work Breakdown Structure 1.4.12.06.02 (Activity Data Sheet 3306, "WAG 6").

\section{DISCLAIMER}

This report was prepared as an account of work sponsored by an agency of the United States Government. Neither the United States Government nor any agency thereof, nor any of their employees, makes any warranty, express or implied, or assumes any legal liability or responsibility for the accuracy, completeness, or usefulness of any information, apparatus, product, or process disclosed, or represents that its use would not infringe privately owned rights. Reference herein to any specific commercial product, process, or service by trade name, trademark, manufacturer, or otherwise does not necessarily constitute or imply its endorsement, recommendation, or favoring by the United States Government or any agency thereof. The views and opinions of authors expressed herein do not necessarily state or reflect those of the United States Government or any agency thereof." 


\section{CONTENTS}

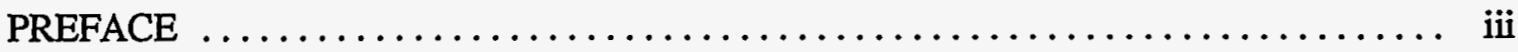

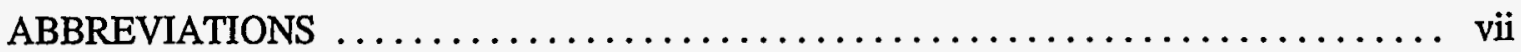

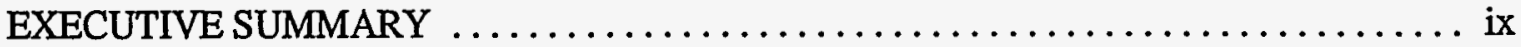

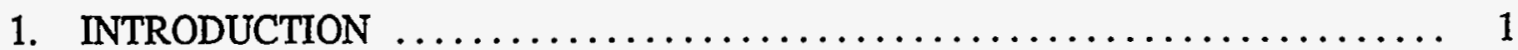

2. GROUND FREEZING FOR ENVIRONMENTAL RESTORATION $\ldots \ldots \ldots \ldots \ldots, 2$

2.1 BACKGROUND AND REVIEW OF GROUND FREEZING $\ldots \ldots \ldots \ldots \ldots .2$

2.2 GROUND FREEZING AS AN ENVIRONMENTAL RESTORATION

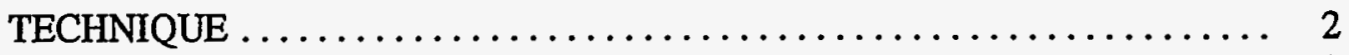

$2.3 \quad$ RESEARCH NEEDS $\ldots \ldots \ldots \ldots \ldots \ldots \ldots \ldots \ldots \ldots \ldots \ldots \ldots \ldots \ldots \ldots, \quad 3$

3. APPLICABILITY OF GROUND FREEZING TO ORNL $\ldots \ldots \ldots \ldots \ldots \ldots \ldots, 4$

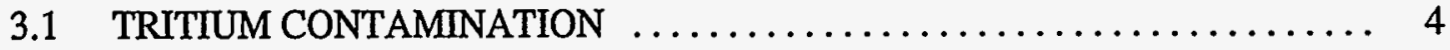

3.2 TREATMENT OF TRITIUM CONTAMINATED GROUNDWATER ........ 4

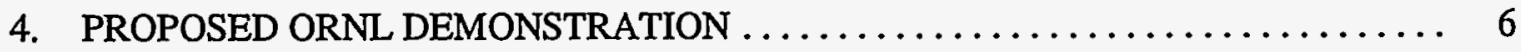

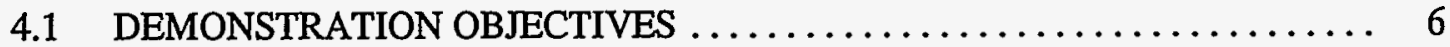

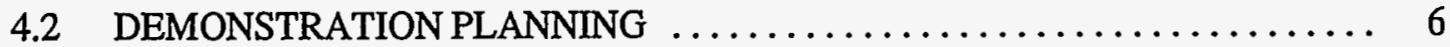

4.3 SITE SELECTION $\ldots \ldots \ldots \ldots \ldots \ldots \ldots \ldots \ldots \ldots \ldots \ldots \ldots \ldots \ldots \ldots \ldots \ldots \ldots \ldots \ldots, \quad 7$

4.4 SITE CHARACTERIZATION $\ldots \ldots \ldots \ldots \ldots \ldots \ldots \ldots \ldots \ldots \ldots \ldots, 8$

4.4.1 Maps $\ldots \ldots \ldots \ldots \ldots \ldots \ldots \ldots \ldots \ldots \ldots \ldots \ldots \ldots \ldots \ldots, 8$

4.4.2 Climatological Data $\ldots \ldots \ldots \ldots \ldots \ldots \ldots \ldots \ldots \ldots \ldots \ldots \ldots, 8$

4.4.3 Hydrological Information $\ldots \ldots \ldots \ldots \ldots \ldots \ldots \ldots \ldots \ldots \ldots, 8$

4.4.4 Soil Information $\ldots \ldots \ldots \ldots \ldots \ldots \ldots \ldots \ldots \ldots \ldots \ldots \ldots \ldots \ldots, 8$

4.4.5 Bedrock Information ............................ 8

4.5 CONCEPTUAL DESIGN OF GROUND FREEZING DEMONSTRATION $\ldots .9$

4.6 LABORATORY SUPPORT STUDIES $\ldots \ldots \ldots \ldots \ldots \ldots \ldots \ldots \ldots \ldots, \quad 9$

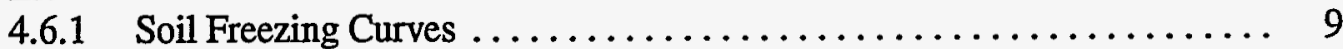

4.6.2 Contaminant Diffusion Rate Studies ...................... 9

4.6.3 Demonstration Design ................................ 9

4.6.4 Field Implementation $\ldots \ldots \ldots \ldots \ldots \ldots \ldots \ldots \ldots \ldots \ldots \ldots, 9$

4.6.5 Monitoring and Evaluation $\ldots \ldots \ldots \ldots \ldots \ldots \ldots \ldots \ldots \ldots, 9$

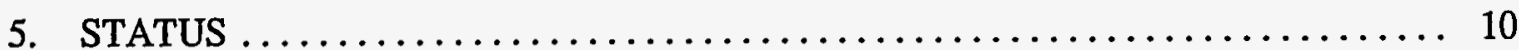

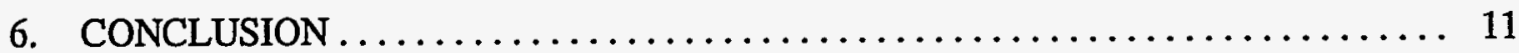

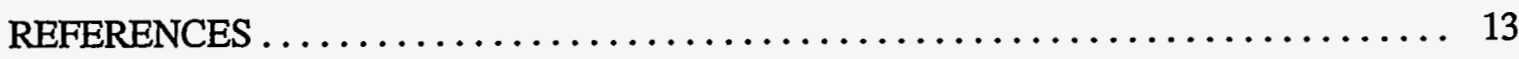




\section{ABBREVIATIONS}

CRREL

DOE

ER

ORNL

WAG
U.S. Army Cold Regions Research and Engineering Laboratory

U.S. Department of Energy

Environmental Restoration

Oak Ridge National Laboratory

Waste Area Grouping 


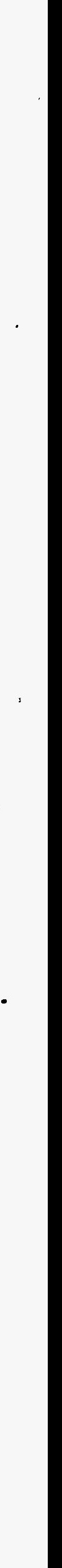




\section{EXECUTIVE SUMMARY}

A study to evaluate the feasibility of using ground freezing technology to immobilize tritium contaminants was performed as part of the Waste Area Grouping (WAG) 6 Technology Demonstrations initiated by the WAG 6 Record of Agreement. The study included a review of ground freezing technology, evaluation of this technology for environmental restoration, and identification of key technical issues. A proposed ground freezing demonstration for containment of tritium at a candidate Oak Ridge National Laboratory site was developed. The planning requirements for the demonstration were organized into seven tasks including site selection, site chartacterization, conceptual design, laboratory evaluation, demonstration design, field implementation, and monitoring design. A brief discussion of each of these tasks is provided. Additional effort beyond the scope of this study is currently being directed to the selection of a demonstration site and the identification of funding. 



\section{INTRODUCTION}

The Oak Ridge National Laboratory (ORNL) Environmental Restoration program (ER) is responsible for the remediation of inactive ORNL disposal sites to reduce the risks to public health and the environment and to achieve regulatory compliance. During review of an ER program Feasibility Study/Proposed Plan for the remediation of Waste Area Grouping (WAG) 6, it was recognized that contaminant releases from WAG 6 posed minimal potential risk to the public and the environment. The U.S. Department of Energy (DOE) in conjunction with the regulators therefore decided to defer remedial action at WAG 6 until higher release sites were first remediated, but recognized the need for technology development for final remediation. As part of the WAG 6 deferred action record of agreement, an Environmental Restoration Technology Development program was established by the ER program to develop and demonstrate innovative technologies for the final remediation of WAG 6 and other ER waste areas. As part of this program, a study to evaluate the feasibility of using ground freezing technology to immobilize tritium contaminants was initiated. The ER sponsored study included participants from the ORNL Environmental Sciences Division and the U.S. Army Cold Regions Research and Engineering Laboratory (CRREL). The scope of the study included a review of ground freezing technology, determination of the feasibility of implementing the technology at ORNL, and the preliminary planning of a potential demonstration at ORNL. This report documents the activities performed during the study. 


\section{GROUND FREEZING FOR ENVIRONMENTAL RESTORATION}

\subsection{BACKGROUND AND REVIEW OF GROUND FREEZING}

Artificial ground freezing has been used for at least 100 years for groundwater seepage control. During ground freezing, ice formation between soil particles increases soil strength and decreases soil permeability. Examples of ground freezing applications include:

- use in coal mines to block groundwater flow,

- formation of retaining walls during deep shaft excavations,

- providing structural support during tunneling operations, and

- forming a seal between earth and concrete in large dams.

Two methods are commonly used to freeze soil. The first method uses a closed-loop system to deliver coolant to the soil, and typically results in a slow to moderate rate of ground freezing. Vertical or horizontal drill holes with steel casing are placed along the desired freezing line and smaller pipes are then inserted inside the casing. In the close-looped freezing system, a header or manifold system is used to deliver coolants such as calcium chloride brine, ethylene glycol or ammonia at temperatures of $-4^{\circ} \mathrm{F}$ to $-20^{\circ} \mathrm{F}$. The coolant is circulated through the region of interest and returned to the refrigeration unit via the annular region of the freeze pipes. Rapid soil freezing systems use an openloop coolant delivery system to deliver an expendable coolant such as liquid nitrogen to the soils to be frozen. An open-loop system has the advantage of achieving a much lower temperature $\left(-30-40^{\circ} \mathrm{F}\right)$ in a shorter period of time. For both slow and fast-rate ground freezing, the spacing between the freeze pipes is between 2 and 8 feet.

\subsection{GROUND FREEZING AS AN ENVIRONMENTAL RESTORATION TECHNIQUE}

Recently, environmental application of ground freezing technology has been considered as a means to manage contaminated sites. Environmental applications of ground freezing include freezing contaminated material prior to excavation to stabilize the material and minimize dust formation, eluting contaminants in front of a freezing front, and isolating and containing contaminated materials in situ. There are several advantages to using ground freezing as an environmental remediation technique including:

- no additives to the soil,

- proven technology for purposes other than environmental restoration,

- system may be turned on/off during emergency,

- frozen soil wall thickness can be controlled by adjusting temperature,

- frozen soil not immediately sensitive to power and other disruptions, and

- once refrigeration is discontinued, all traces of the process can be removed. 


\subsection{RESEARCH NEEDS}

Because the application of ground freezing as an environmental restoration technique is a rather recent development, many technical issues remain to be resolved before this technology can be widely used. Technical issues include:

- The physical processes which will determine the long-term integrity of frozen ground barriers are not known. Also the soil temperatures necessary to achieve reliable containment for different soil textures and mineralogies needs to be established.

- The geochemistry of the pore-water solutions in frozen ground which would effect the state and transport of contaminants and tracers is not well understood.

- The susceptibility of frozen ground barriers to preferential flow phenomena and contaminant transport properties in frozen ground need to be studied further.

- Reliable techniques to assess the physical integrity of frozen ground barriers need to be developed. The suitability of common tracers at frozen ground temperatures needs to be established and sensors for the long-term in situ monitoring of frozen ground barriers are not available. 


\section{APPLICABILITY OF GROUND FREEZING TO ORNL}

ORNL researchers proposed ground freezing as a demonstration technology for tritiated groundwater for several reasons. First, since the tritium oxides behave so much like the bulk water phase it is found in, it is reasonable to expect that the tritium in the free water will be frozen and immobilized in the frozen soil barrier. Also, the impervious nature of the frozen soil barrier should prevent the migration of groundwater and stormflow into the region isolated by the frozen soil barrier. With the tritium in the groundwater immobilized in the frozen soil and the tritium source isolated, this potential flux of tritium can undergo natural radioactive decay to harmless species. If the tritiated water is bound/isolated for a sufficient period of time, the residual level of tritium may no longer be an environmental concern.

\subsection{TRITIUM CONTAMINATION}

Hydrogen found in nature is primarily composed of atoms with one electron and a single proton in the nucleus. Tritium is an isotope of hydrogen which has two neutrons in the nucleus. The tritium isotope of hydrogen $\left(\mathrm{H}_{1}^{3}\right)$ is rarely found in the natural environment, but is known to be produced at facilities generating nuclear power or special nuclear materials. The tritium isotope is unstable and will undergo radioactive decay emitting pure low energy $\beta$ particles (no $\gamma$ rays). Tritium has a half-life of 12.35 years and forms oxides (HTO or $\mathrm{T}_{2} \mathrm{O}$ ) with physical and chemical properties very similar to those of water. One milliliter of pure $\mathrm{T}_{2} \mathrm{O}$ would contain $2,650 \mathrm{Ci}\left(1 \mathrm{Ci}=3.7 \times 10^{10}\right.$ nuclear transformations per second) (Greenwood and Earnshaw 1984). A Federal Maximum Contaminant Level for tritium of $20,000 \mathrm{pCi} / \mathrm{L}$ has been established to minimize human health risk from exposure to tritium.

The presence of tritium contaminated groundwater has been documented at several DOE facilities. Tritium oxides found in tritiated groundwaters would not be expected to be removed from the groundwater and immobilized onto soil matrices by adsorption or other removal processes. Instead, tritium oxides remain solubilized with the groundwater and can readily migrate off-site with natural groundwater flow. Removing tritiated groundwater from the subsurface will prevent migration, but this is not a complete solution because treatment techniques that are used to treat tritiated water at nuclear facilities are not effective treatments for tritiated groundwater.

\subsection{TREATMENT OF TRITIUM CONTAMINATED GROUNDWATER}

Because tritium oxides behave so much like water, it is very difficult to remove tritiated compounds from contaminated groundwater. Treatment processes that are used to remove tritium from water at nuclear facilities can not be applied to tritiated groundwater for several reasons including; (1) dilute concentration of tritium in groundwater compared to concentration equipment is designed for, (2) fouling of equipment by other constituents in groundwater and (3) high capital and operating cost for ex-situ tritium removal (separation) processes (Nixon 1992).

Technologies for treating tritiated groundwater on site are in the developmental stage. One such process is tritium treatment by extraction and injection. This process "treats" tritium contaminated groundwater by extracting the contaminated groundwater, treating the extracted water above-ground to remove other contaminants and then injecting the partially treated water back into the contaminated site up gradient from the extraction site. This process is repeated several times and tritium treatment 
is accomplished over time naturally by radioactive decay during recycling (Nixon 1992). Another technology being evaluated is the evaporative removal of tritium by bubbling humidified air through soil containing tritiated groundwater. With this process, tritium oxide is transferred from the aqueous phase to the vapor phase where it can then be removed from the subsurface by off-gassing into the atmosphere. 


\section{PROPOSED ORNL DEMONSTRATION}

\subsection{DEMONSTRATION OBJECTIVES}

A field scale demonstration of ground freezing was proposed to investigate the isolation and immobilization of tritiated groundwater leaching from an actual tritium-contaminated waste disposal trench. The goal of the proposed demonstration was to address the following technical issues related to the environmental application of ground freezing technology:

- Will a frozen barrier of soil be able to both immobilize tritium in the free water found in soil to be frozen and prevent the migration of water into the isolated region?

- What are the short and long term costs associated with installing, operating, and maintaining an ice wall in a radiologic controlled zone? Since the design life of the frozen soil barrier may require several tritium half-lives, a time period of 25 to 50 years or more, issues related to replacement of freezer points, monitoring for leaks and brine pools, and refrigeration plant replacement are important economic issues. Typical civil engineering applications take about $1 / 10$ the time envisioned for full-scale immobilization of tritium.

- Are the hydro geological properties of the demonstration site (groundwater flow patterns, soil chemistry, and stratigraphy) amenable to ground freezing?

- Will ground freezing require supporting technologies (i.e., grouting) to eliminate possible defects in the ice barrier due to locally high seepage velocities or pools of water possible in the karstic geology at ORNL?

- How can the integrity of the subsurface frozen barrier be monitored and how will performance of the barrier be measured?

- How will the frost heaving that results from ground freezing effect the contents of the trench being isolated?

- How will the sub surface frozen ground barrier effect groundwater flow patterns and possibly the transport of other contaminants?

- How does the increase in pore fluid and volumetric expansion of the soil pore structure due to ground freezing influence groundwater movement after the ice barrier is removed?

\subsection{DEMONSTRATION PLANNING}

The proposed demonstration was organized into seven subtasks:

1. Site Selection.

2. Site Characterization.

3. Conceptual Design of Ground Freezing Demonstration. 
4. Laboratory Evaluation of Soil Freezing Properties.

5. Demonstration Design.

6. Field Implementation.

7. Monitoring and Evaluation.

An interagency agreement was established with CRREL to facilitate the design of the field demonstration (Energy Systems 1993, Department of the Army 1993).

\subsection{SITE SELECTION}

The goal of the first subtask was to identify a tritium contaminated site that would be suitable for a ground freezing demonstration. Site selection criteria were developed with input for scientist at CRREL. The primary site selection criteria are summarized below:

- A significant quantity of the tritium or other contaminants of concern should not be located in the region to be frozen. Excessive tritium levels in the surrounding area would make monitoring the frozen barrier performance difficult. An ideal situation would be to locate a tritium contaminated trench were tritium has not leached beyond the trench boundaries.

- The demonstration site should be accessible with sufficient room for equipment to maneuver around the barrier. The site should not be in a heavily forested area.

- The demonstration site should have a gradient from 2 to $10 \%$. The ground surface should be sloped to promote proper drainage but should not be so steep that it would be difficult for the drilling equipment to operate.

- When freezing is begun, sufficient water should be in the nearby soil or groundwater so that the ground freezes quickly and completely and forms a continuous barrier.

- Soils which are more than $50 \mathrm{ft}$ above the water table should be fine textured silts or clays to insure that a continuous barrier is formed with minimum frost heaving.

- If the lower surface of the frozen barrier is to be established in rock, that rock should be below the water table. If the bottom of the barrier is to be in situ unfrozen earth material, then the depth to an impervious soil stratum or bedrock should be less than 50 feet. Pipe installation costs at depths greater than 50 feet would be excessive.

- If part of the barrier is to be established below the water table, the groundwater velocity should be less than 2 meters per day, preferably less than 1 meter per day. If the groundwater flow rate is too high, it will be impossible to freeze a continuous wall and achieve closure using an economical freeze pipe spacing. 


\subsection{SITE CHARACTERIZATION}

The goal of this subtask was to collect the site characterization information that would be required for design of the ground freezing barrier. An additional objective to was to collect samples for the laboratory studies from the selected demonstration site at the same time site characterization samples are obtained. The type of site information that will be required to design and implement a ground freezing demonstration should be easily obtained from existing site information and selected sampling of the demonstration site. Information requirements for a successful ground freezing demonstration were prepared by researchers at CRREL and are summarized in the subsections below.

\subsubsection{Maps}

- Topographic maps from the U.S. Geological Survey

- Full-scale maps of test area and trenches

\subsubsection{Climatological Data}

- Mean monthly temperatures

- Mean monthly precipitation

- Mean depth of frost penetration

- Freezing index for area

- Measured or estimated evaporation and evapotranspiration rates

- Wind direction and speed

\subsubsection{Hydrological Information}

- Groundwater flow rates and directions at different time of the year

- Groundwater table depth, inclination and slope

- Bedrock groundwater information

\subsubsection{Soil Information}

- Dry bulk density

- Moisture content

- Organic content

- Grain-size analysis of mineral fractions

- Heat capacity

- Thermal conductivity

- Liquid limits

- Hydraulic conductivity

\subsubsection{Bedrock Information}

- Permeability

- Compressive strength

- Density

- Porosity

- Schistosity 


\subsection{CONCEPTUAL DESIGN OF GROUND FREEZING DEMONSTRATION}

In order to allow the preparation of cost estimates and schedules, a preliminary design was prepared for the isolation of a single tritium contaminated trench by a frozen ground barrier. The conceptual design included isolating a single contaminated trench with a frozen ground barrier $8 \mathrm{ft}$ thick in the configuration of a V-shaped enclosure with vertical ends. The frozen ground barrier would be formed by one row of freeze pipes located around the perimeter of the trench to be isolated. Piping, installation, refrigeration, and maintenance cost were estimated for the formation of a frozen soil barrier around a trench $15 \mathrm{ft}$ wide by $10 \mathrm{ft}$ deep by $160 \mathrm{ft}$ long. In order to fully contain any tritium that may have leached from the trench, the frozen barrier was designed to extend to a depth of $42 \mathrm{ft}$. The design life of the conceptual demonstration was 5 years. The preliminary budget and schedule prepared for proposed demonstration are listed in the References chapter of this document.

\subsection{LABORATORY SUPPORT STUDIES}

The information obtained during the site characterization task would need to be combined with data from laboratory studies with site soil before an actual frozen ground barrier can be designed. Two types of laboratory studies were to be conducted by researchers at CRREL.

\subsubsection{Soil Freezing Curves}

A soil freezing curve is the relationship between temperature and liquid water content of saturated frozen soils. Analyses would be made by pulsed nuclear magnetic resonance, a technique developed at CRREL. The soil freezing curves will provide information that can be used in the design of the frozen ground barrier. For barrier monitoring, in situ soil freezing curves will allow estimates of soil liquid water contents, and by extension hydraulic conductivities and diffusion rates, based on soil temperature measurements.

\subsubsection{Contaminant Diffusion Rate Studies}

These experiments will determine the diffusion rate of ${ }^{3} \mathrm{H}$ and any other contaminants of interest in native soils from a selected demonstration site.

\subsubsection{Demonstration Design}

Work on this task was not initiated.

\subsubsection{Field Implementation}

Work on this task was not initiated.

\subsubsection{Monitoring and Evaluation}

Work on this task was not initiated. 


\section{STATUS}

During Fiscal Year 94, considerable effort was extended to develop the proposed ground freezing demonstration. An interagency agreement with CRREL was established after ORNL staff members visited the CRREL facilities to evaluate on-site research facilities and to explore research areas of mutual interest. Researchers from CRREL visited ORNL on two separate occasions to view potential demonstration sites and to discuss sample retrieval and handling protocol. The primary deterrent to the progress of the demonstration was the inability to identify a suitable site for a demonstration. While there are many documented tritium contaminated sites in WAG 5, the overall extent of contamination, the close proximity of the trenches to each other, and the uncertainty regarding actual trench locations made the identification of a specific trench suitable for a ground freezing demonstration difficult. 


\section{CONCLUSION}

No work was performed on the project in Fiscal Year 95, however, a potential ground freezing demonstration at ORNL is currently being evaluated by a combined ER/Office of Technology Development/Waste Management committee. Sites under consideration included areas in WAG 5 and WAG 4. A tritium containing trench at WAG 4 was selected by the committee. Funding options are currently under review. 


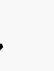




\section{REFERENCES}

Energy Systems (Martin Marietta Energy Systems, Inc.). 1993. Interagency Agreement No. DE-AI05-94OR22141. Oak Ridge National Laboratory and U.S. Army Corps of Engineers, Cold Regions Research and Engineering Laboratory.

Energy Systems (Martin Marietta Energy Systems, Inc.). 1993. Cryogenic Immobilization of Tritium: Detail Report. 1994. Oak Ridge, TN.

Energy Systems (Martin Marietta Energy Systems, Inc.). 1993. WAG 6 Cryogenics: Fiscal Year Summary. 1994.Oak Ridge, TN.

Greenwood, N. N., and A. Earnshaw.1984. Chemistry of the Elements. Pergamon Press Ltd. Elmsford, NY.

Department of the Army. 1993. "Cyrogenic Demonstration at Oak Ridge National Laboratory," Proposal to Oak Ridge National Laboratory Environmental Sciences Division, Draft Interagency Agreement. Cold Regions Research and Engineering Laboratory, Corps of Engineers, Hanover, NH.

Nixon, P. and L. St. Clair, 1992. "Groundwater Extraction and Injection to Control Tritium Plumes at Nuclear Facilities," Proceedings of the 1992 U.S. EPA/A\&WMA International Symposium. Pittsburgh, PA. 


\section{DISTRIBUTION}

1. H. L. Boston

2. W. D. Brickeen

3. D. L. Garrett

4. D. Gates

5. C. S. Haas

6. C. M. Kendrick

7. A. J. Kuhaida

8. A. P. Malinauskas

9-10. D. M. Matteo

11-12. P. T. Owen

13. P. A. Schrandt

14. P. S. Wood

15. Central Research Library

16-18. ER Central Document Management Center

19. Laboratory Records Department

20. Office of Assistant Manager for Energy Research and Development, DOE Oak Ridge Operations Office, P. O. Box 2001, Oak Ridge, TN 37831-8600

21-22. ORNL ER Document Management Center

23. ORNL Laboratory Records

24. J. Kubarewicz, Jacobs Engineering Group, Inc., 125 Broadway, Oak Ridge, TN 37830

25. R. Peters, Scientific Ecology Group, 1560 Bear Creek Road, Oak Ridge, TN 37830

26. Office of Scientific and Technical Information, P. O. Box 62, Oak Ridge, TN 37831 


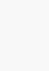

, 
Please do not forward or discard this document.

If this address is not correct for the designated addressee, please return this document to the

ER Central Document Management Center Building K-1002, MS 7243

Lockheed Martin Energy Systems, Inc.

P.0. Box 2003

Oak Ridge, TN 37831 